\title{
EVALUATION OF SOME PROMISING SUGARCANE GENOTYPES FOR RATOONING ABILITY
}

\author{
Shalaby, N.M.E. \\ Variety Maintenance Dept, Sugar Crops Res. Inst, ARC, Giza, Egypt
}

\begin{abstract}
A field experiment was conducted during 2008-2012 in Shandweel Research Station, Sohag Governorate (latitude of $26^{\circ} .55$ $\mathrm{N} \&$ longitude of $31^{\circ} .7 \mathrm{E}$ ) to study the ratooning ability of five promising sugarcane varieties, viz. G.84-47, G.2003-47, G.2003-49, G.98-28, G.99-160 compared to the commercial G.T.54-9 variety. The tested varieties were arranged in a randomized complete block design in three replications. The evaluated genotypes were assessed for their regeneration capacity based on number of stalks $/ \mathrm{m}^{2}$, stalk diameter, sucrose, cane and sugar yields up to $2^{\text {nd }}$ ratoon.

The tested genotypes significantly differed in sucrose content, cane and sugar yields. Among the studied genotypes, G.2003-47, consistently maintained the highest cane yield/fed, while the commercial variety produced the highest sugar yield as compared to the other genotypes up to the $2^{\text {nd }}$ ratoon crop.

It was found that G.2003-47 genotypes possesses better multiratooning ability with high cane and sugar yields and could be exploited successfully beside the commercial variety G.T.54-9.
\end{abstract}

Key words: Sugarcane, ratonning ability, varietiesm.

INTRODUCTION:

Good ratooning in sugarcane is beneficial for the farming community as its production costs are lower than that of the plant crop. However, during the last few years, ratoon crop of sugarcane has shown a declining tendency in cane yield. Almost all of the locally introduced sugarcane genotypes as G.85-37 and Phil.80-13 have shown this trend (Azzazy et al, 2005 and Abd El-Aal et al, 2007).

Low yield of ratoon crop is mainly due to low and differential ratooning potential of cultivars and suboptimal crop management. Ratoon keeping in sugarcane is economical for the farming community of which production cost is lower than plant

crop by $25-30 \%$ along with saving of seed material. A ratoon crop matures prior to plant crops, thus ensuring early supply of canes to mills. Under similar conditions, sugarcane ratoon have a supplementary advantage of better juice quality and sugar recovery than those of plant crop of the same variety (Yadav, 1991). Shahid et al (2013) reported that the plant crop of all the sugarcane genotypes grown in Punjab (Pakistan) should preferably be harvested in February for subsequent better ratooning and more cane and sugar yields. Therefore, it brings more economic return not only for the farmers but also for the sugar industry.

Ratooning ability is one of the important economic considerations in many sugarcane growing countries to decide the suitability of sugarcane varieties for commercial cultivation. Genetic variation among sugarcane genotypes for ratooning potential has been reported by many researchers

Fayoum J. Agric. Res. \& Dev., Vol. 27, No.1, January, 2013 
among them Bhatnagar et al. (2003) and Rafiq et al. (2006).

Since the reduction in cane yield of ratoon crops is the major problem for sugarcane growers in Egypt. The prime objective of this study was to identify the distinct sugarcane genotypes characterized with their good ratooning/ stubbling ability under the agro-climatic conditions of Sohag Governorate.

\section{MATERIALS AND METHODS}

A field experiment was conducted during 2008-2011 to evaluate the performance of some sugarcane genotypes grown in a crop cycle of one plant cane and two ratoon crops, which was repeated during 2009-12, to identify the distinct genotypes for multiratooning up to $2^{\text {nd }}$ ratoon at Shandweel Research Station, Sohag Governorate. The soil analysis of the experimental site showed that the soil was clay-loam consisting, 55.2 and $60.1 \%$ clay, 28.9 and $24.8 \%$ silt and 13.2 and $10.1 \%$ sand, with $\mathrm{pH}$ of 7.4 and 7.5 , available nitrogen of (48.9 and 57.6 ppm) and 2.1 and $1.9 \% \mathrm{CaCO}_{3}$ ) in 2008/2009 and 2009/2010 season, respectively (the $1^{\text {st }}$ and $2^{\text {nd }}$ plant cane crops).

Five promising sugarcane genotypes, viz. Giza 84-47, Giza 2003-47, Giza 2003-49, Giza 98-28, Giza 99-160 in addition to the commercial Giza Tayien 54-9 variety were assessed for their ratooning ability under a crop cycle of a plant cane, $1^{\text {st }}$ and $2^{\text {nd }}$ ratoon crops, in a randomized block design in three replications. Unit area was $42 \mathrm{~m}^{2}$. represents six rows, one $\mathrm{m}$ in wide and $7 \mathrm{~m}$ in length. Recommended doses of $\mathrm{N}, \mathrm{P}$ and $\mathrm{K}$ fertilizers $(210 \mathrm{~kg} \mathrm{~N}, 30 \mathrm{~kg}$ $\mathrm{P}_{2} \mathrm{Q}_{2} \& 48 \mathrm{~kg} \mathrm{~K} \mathrm{~K}_{2} \mathrm{O} / \mathrm{fed}$, respectively) were applied for the plant canes and ratoon crops. Sugarcane crops were harvested at age of 12 months.

1. At harvest the fourth guarded rows were harvested, topped and cleaned to determined cane yield (t/fed.). 2. A sample of 25 stalk was collected randomely from each plot to determine apparent sucrose content (pol\% cane) according to A.O.A.C. (1990). 3. Sugar yield (t/fed), was calculated by multiplying pol\% by cane yield/fed.

Statistical Analysis: A combined analysis over the two crop cycles (the trend of the results for both cycles was similar) was done according to Gomez and Gomez (1984). Means were compared by Fisher's least significant difference (LSD) according to Steel and Torrie, (1980).

\section{RESULSTS AND DISCUSSION}

\section{Number of $s$ talks $/ \mathrm{m}^{2}$ :}

The combined data of the two cycles in Table 1 show that the number of sugarcanes $/ \mathrm{m}^{2}$ was significantly different. The results cleared that the number of sugarcanes $/ \mathrm{m}^{2}$ was increased by 0.33 and $0.59 \mathrm{stalk} / \mathrm{m}^{2}$ for sugarcane grown as a $1^{\text {st }}$ ratoon and $2^{\text {nd }}$ ratoon, respectively.

The collected data pointed out to a significant difference among the evaluated sugarcane genotypes over combining analysis of the $1^{\text {st }}$ and $2^{\text {nd }}$ crop cycles. Sugarcane genotype G. 2003-49 attained the highest mean value of this trait, without significant variance with that recorded by G. 99-160 and G. 9828. The differences among the tested genotypes could be attributed to the variance in their gene make-up.

In general, good ratooners are characterized by good tillering habit in the plant cane crop, which results in well developed underground branches with a higher number of nodes and buds and enough stored nutrients. When timely cultural operations, especially furrowing, hoeing (earthing-up) are practiced,

Fayoum J. Agric. Res. \& Dev., Vol. 27, No.1, January, 2013 
the buds sprout and rapidly regenerate and hence participate to the following ratoon.

Regarding the interaction effect, the results in Table (1) manifest that the number of canes $/ \mathrm{m}^{2}$ was markedly influenced by the interactions among sugarcane genotypes and crop cycles. Combined data showed that the variance between G. 84-47 and G.T.54-9 in this trait was insignificant when they were grown as plant cane or a ${ }^{\text {st }}$ ratoon. However, the difference between the two varieties reached the level of significance in the $2^{\text {nd }}$ rotoon cane crop.

Table 1: Number of stalks $/ \mathrm{m}^{2}$ of sugarcane genotypes as influenced by different ratooning up to $2^{\text {nd }}$ ratoon (combined analysis over two crop cycles)

\begin{tabular}{|l|c|c|c|c|}
\hline \multirow{2}{*}{\multicolumn{1}{|c|}{ Genotype }} & \multicolumn{3}{c|}{ Number of stalks/m } & \multirow{2}{*}{ Mean } \\
\cline { 2 - 4 } & \multicolumn{3}{|c|}{ Crop Cycle } & \\
\cline { 2 - 4 } & Plant cane & $\mathbf{1}^{\text {st }}$ ratoon & $\mathbf{2}^{\text {nd }}$ ratoon & \\
\hline G. 84-47 & 10.83 & 11.67 & 12.00 & $\mathbf{1 1 . 5 0}$ \\
\hline G. 2003-47 & 10.93 & 11.33 & 11.67 & $\mathbf{1 1 . 3 1}$ \\
\hline G. 2003-49 & 11.87 & 12.27 & 12.17 & $\mathbf{1 2 . 1 0}$ \\
\hline G. 99-160 & 11.33 & 11.67 & 12.33 & $\mathbf{1 1 . 7 8}$ \\
\hline G. 98-28 & 12.00 & 11.67 & 12.00 & $\mathbf{1 1 . 8 9}$ \\
\hline G.T.54-9 & 9.97 & 10.33 & 10.33 & $\mathbf{1 0 . 2 1}$ \\
\hline Mean & $\mathbf{1 1 . 1 6}$ & $\mathbf{1 1 . 4 9}$ & $\mathbf{1 1 . 7 5}$ & - \\
\hline
\end{tabular}

LSD at 0.05 level

Crop cycle $(\mathbf{C})$

0.15

Cane genotype (G)

0.41

C x G

1.65

\section{Stalk diameter:}

Data in Table (2) show that rationing up to the $2^{\text {nd }}$ ratoon had insignificant effect on cane stalk diameter.

With regard to the differences among the tested sugarcane genotypes, G. 99-160 had the thickest cane stalks without any significant differens with G. 2003-49, G. 98-28 and/or G.T.54-9. Moreover, G.84-47 had the thinnest stalks over the two crop cycles. The differences among the tested genotypes could be due to the variance in there genetic structure.

As for the interaction effect, cane stalk diameter was significantly affected by the interactions among sugarcane genotypes and crop cycles. Over two crop cycles, the results in Table (2) clear that the variance between G. 84-47 and G.98-28 in this trait was insignificant when they were grown as plant cane or a $1^{\text {st }}$ ratoon. However, the difference between the abovementioned genotypes was significant in the $2^{\text {nd }}$ ratoon.

Fayoum J. Agric. Res. \& Dev., Vol. 27, No.1, January, 2013 
Table 2: Number of stalk diameter $(\mathrm{cm})$ of sugarcane genotypes as influenced by different ratooning up to $2^{\text {nd }}$ ratoon (combined analysis over two crop cycles)

\begin{tabular}{|l|c|c|c|c|}
\hline \multirow{2}{*}{ Genotype } & \multicolumn{3}{|c|}{ Stalk diameter (cm) } & \multirow{2}{*}{ Mean } \\
\cline { 2 - 4 } & \multicolumn{3}{|c|}{ Crop Cycle } & \\
\cline { 2 - 4 } & Plant cane & $\mathbf{1}^{\text {st }}$ ratoon & $\mathbf{2}^{\text {nd }}$ ratoon & \\
\hline G. 84-47 & 2.37 & 2.33 & 2.27 & $\mathbf{2 . 3 2}$ \\
\hline G. 2003-47 & 2.53 & 2.50 & 2.50 & $\mathbf{2 . 5 1}$ \\
\hline G. 2003-49 & 2.53 & 2.50 & 2.53 & $\mathbf{2 . 5 2}$ \\
\hline G. 99-160 & 2.60 & 2.63 & 2.63 & $\mathbf{2 . 6 2}$ \\
\hline G. 98-28 & 2.60 & 2.53 & 2.57 & $\mathbf{2 . 5 7}$ \\
\hline G.T. 54-9 & 2.57 & 2.53 & 2.50 & $\mathbf{2 . 5 3}$ \\
\hline Mean & $\mathbf{2 . 5 3}$ & $\mathbf{2 . 5 1}$ & $\mathbf{2 . 5 0}$ & - \\
\hline LSD at 0.05 level \\
Crop cycle (C) \\
Cane genotype (G) \\
C x G
\end{tabular}

\section{Juice Sucrose percentage:}

The combined data in Table (3) of the two studied crop cycles (2008-2011 and 2009-2012) indicate that cane juice sucrose \% reached its highest value in the $1^{\text {st }}$ ratoon recording significantly $0.36 \%$ higher than that given by sugarcane grown as a plant cane crop, thereafter, it insignificantly decreased by $0.03 \%$ as compared with its value in the $2^{\text {nd }}$ ratoon crop. These results could be due to the fact that the duration from grand growth stage up to maturity is shorter in the plant cane crop than that of the $1^{\text {st }}$ ratoon, where plants of plant cane crop spend about three months after planting of cane cuttings to germinate and emerge, until they reach a stable number of millable stalks (after competition among the emerged shoots), while plants of the $1^{\text {st }}$ ratoon use the root system that was already built-up by the plant cane crop, i.e. they have a longer season to grow and to accumulate more sugar than the plant cane crop. Moreover, the higher number of stalks and thinner plants (Table 1 and 2 , respectively) in the $2^{\text {nd }}$ ratoon crop compared with those of the $1^{\text {st }}$ ratoon, as well as the competition among plants of the $2^{\text {nd }}$ ratoon crop for growth elements as solar radiation, water and nutrients have decreased their potential of sugar accumulation compared with those of the $1^{\text {st }}$ ratoon. These results are in agreement with that reported by Perumal, (1981) who mentioned that ratoon crop, in general, is earlier to mature than plant crop and is known to have higher sugar content than plant crop.

The results in Table (3) show insignificant difference among the evaluated sugarcane genotypes in juice sucrose content. However, it could be noticed that both of G.2033-47 and G.2003-49 genotypes attained the highest sucrose percentage compared with the other ones.

Concerning the interaction effect, there was insignificant difference in sucrose \% of G.2003-47 and G.T.54-9 as affected by the interaction between sugarcane genotype and crop cycle when they were grown as a plant cane or $1^{\text {st }}$ ratoon. However, the difference between them in this quality characteristic was significant in the $2^{\text {nd }}$ ratoon.

Fayoum J. Agric. Res. \& Dev., Vol. 27, No.1, January, 2013 
EVALUATION OF SOME PROMISING SUGARCANE.

Table 3: Number of sucrose \% of sugarcane genotypes as influenced by different ratooning up to $2^{\text {nd }}$ ratoon (combined analysis over two crop cycles)

\begin{tabular}{|c|c|c|c|c|}
\hline \multirow{3}{*}{ Genotype } & \multicolumn{3}{|c|}{ Sucrose percentage } & \multirow{3}{*}{ Mean } \\
\hline & \multicolumn{3}{|c|}{ Crop Cycle } & \\
\hline & Plant cane & $1^{\text {st }}$ ratoon & $2^{\text {nd }}$ ratoon & \\
\hline G. 84-47 & 16.45 & 17.04 & 16.40 & 16.63 \\
\hline G. 2003-47 & 17.06 & 17.45 & 17.91 & 17.47 \\
\hline G. 2003-49 & 16.76 & 17.21 & 17.41 & 17.13 \\
\hline G. 99-160 & 14.89 & 15.47 & 15.47 & 15.28 \\
\hline G. 98-28 & 14.69 & 14.85 & 14.64 & 14.73 \\
\hline G.T. 54-9 & 15.76 & 15.76 & 15.81 & 15.77 \\
\hline Mean & 15.94 & 16.30 & 16.27 & \\
\hline \multicolumn{5}{|l|}{ LSD at 0.05 level } \\
\hline $\begin{array}{l}\text { Crop cycle (C) } \\
\text { Cane genotype (G) }\end{array}$ & & & & $\begin{array}{l}1.1 \\
\text { NS } \\
1.8\end{array}$ \\
\hline
\end{tabular}

\section{Cane yield:}

The combined data in Table (4) show that the highest cane yield/fad was produced by sugarcane grown as a $1^{\text {st }}$ ratoon crop, which increased (insignificantly) the plant cane by $4.30 \mathrm{t} / \mathrm{fad}$ and the $2^{\text {nd }}$ ratoon (significantly) by $8.32 \mathrm{t} / \mathrm{fed}$. These results may be attributed to final output of the relation between the number of millable stalks and stalk diameter (Tables 1 and 2) recorded at the $1^{\text {st }}, 2^{\text {nd }}$ and $3^{\text {rd }}$ years of the crop cycle, where the highest cane yield/fad was produced from cane plants having medium number of cane stalks and diameter, rather than higher number of thinner stalks or lower number of thicker stalks.

The results manifested the significant superiority of G. 2003-47 over the other tested sugarcane genotypes in cane yield/fad, where it attained 9.73 , $8.47,22.03,26.47$ and 5.93 t of canes higher than that produced by G.84-47, G. 2003-49, G. 99-160, G. 98-28 and G.T.54-9, respectively. Meanwhile, there was insignificant difference in cane yield between G. 84-47 and G. 200349; and between G. 2003-49 and G.T.54-9. The difference among the evaluated cane genotypes may be referred to the variation of their genetic structure.

With regard to the performance of the tested sugarcane genotypes during the studied crop cycles, it was found that cane yield/fad of all genotypes was increased in the $1^{\text {st }}$ ratoon compared with those produced by cane. In this respect, G.2003-47 attained the highest increase among genotypes in cane yield amounted to 12.8 tons/fad. However, its cane yield was decreased by $14.2 \mathrm{t} / \mathrm{fad}$ in the $2^{\text {nd }}$ ratoon compared with that gained in its $1^{\text {st }}$ ratoon. Meantime, this genotype kept the $1^{\text {st }}$ rank among genotypes in the mean value recorded in the whole crop cycle. Likewise, cane yield of G.99160 increased by $3.2 \mathrm{t} /$ fad in the $1^{\text {st }}$ ratoon compared with that recorded by its plant cane, but it was decreased by $10.1 \mathrm{t} / \mathrm{fad}$ in the $2^{\text {nd }}$ ratoon, compared to the $1^{\text {st }}$ one. Similar results were noticed for G.98-28 genotype, where its cane yield was increased by $2.3 \mathrm{t} / \mathrm{fad}$, and thereafter decreased by $7.8 \mathrm{t} / \mathrm{fad}$, in the $1^{\text {st }}$ and $2^{\text {nd }}$ ratoon, respectively. In general, good ratooners are characterized by good tillering habit in the plant cane crop, which results in well developed underground branches with a higher number of nodes and buds and enough

Fayoum J. Agric. Res. \& Dev., Vol. 27, No.1, January, 2013 
stored nutrients. When timely cultural operations, especially furrowing, hoeing (earthing-up) are practiced, the buds sprout and rapidly regenerate and hence participate to the following ratoon. The obtained results showed that the three four mentioned genotypes are poor in ratooning as crop cycle was increased up to the $2^{\text {nd }}$ ratoon. Excluding the genetic make-up influencing the performance of genotypes, the compaction of soil surface with the continuity of crop cycle resulted from means of loading and transportation of the crop participates to the overall reduction of their cane yield recorded at the $2^{\text {nd }}$ ratoon. According to Ethirajan et al. (1976) and Singh (1981) the most important factor that determines the yield of ratoon crop was the number of shoots available in the field. Mather (1987) emphasized that gappy uneven ratoon cumulatively accounts for low yields. Gap filling resulted in higher cane yield in ratoon (Durai and Ahmed, 1988). Similar results were also observed by Kathiresan and Manickan (2001).

Table 4: Number of cane yield (ton/fad) of sugarcane genotypes as influenced by different ratooning up to $2^{\text {nd }}$ ratoon (combined analysis over two crop cycles)

\begin{tabular}{|c|c|c|c|c|}
\hline \multirow{3}{*}{ Genotype } & \multicolumn{3}{|c|}{ Cane yield (t/fad) } & \multirow{3}{*}{ Mean } \\
\hline & \multicolumn{3}{|c|}{ Crop Cycle } & \\
\hline & Plant cane & $1^{\text {st }}$ ratoon & $2^{\text {nd }}$ ratoon & \\
\hline G. 84-47 & 52.1 & 54.3 & 48.3 & 51.57 \\
\hline G. 2003-47 & 57.5 & 70.3 & 56.1 & 61.30 \\
\hline G. 2003-49 & 53.2 & 55.1 & 50.2 & 52.83 \\
\hline G. 99-160 & 40.5 & 43.7 & 33.6 & 39.27 \\
\hline G. 98-28 & 35.9 & 38.2 & 30.4 & 34.83 \\
\hline G.T. 54-9 & 55.4 & 58.8 & 51.9 & 55.37 \\
\hline Mean & 49.10 & 53.40 & 45.08 & \\
\hline \multicolumn{5}{|l|}{ LSD at 0.05 level } \\
\hline \multicolumn{4}{|c|}{ Cane genotype (G) } & 2.9 \\
\hline \multicolumn{4}{|c|}{ CxG } & 6.8 \\
\hline
\end{tabular}

5. Sugar yield:

The combined data over two crop cycles in Table (5) indicate that growing sugarcane in a crop cycle including a plant cane, $1^{\text {st }}$ and $2^{\text {nd }}$ ratoons had a significant effect on the produced sugar yield/fad. The results pointed out that the highest sugar yield/fad was produced from sugarcane grown as a $1^{\text {st }}$ ratoon, which out-yielded that extracted from cane crop and the $2^{\text {nd }}$ ratoon by 0.89 and $1.35 \mathrm{t}$ of sugar, respectively. Meanwhile, sugarcane grown as a $2^{\text {nd }}$ ratoon attained $0.46 \mathrm{t}$ of sugar/fad compared with that gained by the plant cane crop. These results are probably due to the same trend of sucrose percentage and cane yield/fad (Tables 3 and 4), which are the main components of extractable sugar yield. In deed, the ratoon crop of sugarcane has ample scope of improvement in sugar productivity as it has higher sugar content than plant crop, which basically due to the longer sugar accumulation period than that of the plant cane crop.

With regard to the genotypic variance, the results cleared that the tested sugarcane genotypes were significantly different in their sugar yield/fad. Sugarcane G. 2003-47 genotype surpassed G. 84-47, G. 2003-49, G. 99-160, G.99-160 and G.T.54-9 by $2.13,1.31,4.85,5.60$ and 1.84 ton sugar/fad,

Fayoum J. Agric. Res. \& Dev., Vol. 27, No.1, January, 2013 
EVALUATION OF SOME PROMISING SUGARCANE..........

respectively. On the other hand, the lowest sugar yield/fad was recorded by G.98-28. This is an indication of a great genetic variation among genotypes reflected on their performance and yield potential. These results are a logic expression of the final output of both sucrose $\%$ and cane yield/fad participating in the sugar yield/fad, which data are collected in Tables 3 and 4.

Table (5): Number of sugar yield ( $t /$ fad) of sugarcane genotypes as influenced by different ratooning up to $2^{\text {nd }}$ ratoon (combined analysis over two crop cycles)

\begin{tabular}{|l|c|c|c|c|}
\hline \multirow{2}{*}{ Genotype } & \multicolumn{3}{|c|}{ Sugar yield (t/fad) } & \multirow{2}{*}{ Mean } \\
\cline { 2 - 4 } & \multicolumn{3}{|c|}{ Crop Cycle } & \\
\cline { 2 - 4 } & Plant cane & $\mathbf{1}^{\text {st }}$ ratoon & $\mathbf{2}^{\text {nd }}$ ratoon & $\mathbf{8 . 5 8}$ \\
\hline G. 84-47 & 8.57 & 9.25 & 7.92 & $\mathbf{1 0 . 7 1}$ \\
\hline G. 2003-47 & 9.81 & 12.27 & 10.05 & $\mathbf{9 . 0 5}$ \\
\hline G. 2003-49 & 8.92 & 9.48 & 8.74 & $\mathbf{6 . 0 0}$ \\
\hline G. 99-160 & 6.03 & 6.76 & 5.20 & $\mathbf{5 . 1 3}$ \\
\hline G. 98-28 & 5.27 & 5.67 & 4.45 & $\mathbf{8 . 7 3}$ \\
\hline G.T.54-9 & 8.73 & 9.27 & 8.21 & \\
\hline Mean & $\mathbf{7 . 8 9}$ & $\mathbf{8 . 7 8}$ & $\mathbf{7 . 4 3}$ & \\
\hline
\end{tabular}

LSD at 0.05 level

Crop cycle (C)

0.43

Cane genotype (G)

0.32

$\mathbf{C} \mathbf{x} \mathbf{G}$

0.71

The results in Table 5 point to a significant influence of the interaction between sugarcane genotype and crop cycle. However, the results showed insignificant variance in sugar yield among the two commercial cultivars viz. G.T. 54-9 and G.84-47 grown as a plant cane crop, $1^{\text {st }}$ and/or $2^{\text {nd }}$ ratoon. On the other hand, it was found that the difference between the promising genotype G.2003-49 and G.84-47 cultivar in sugar yield was insignificant in the plant cane and the $1^{\text {st }}$ ratoon, while it was significant in the $2^{\text {nd }}$ ratoon crop.

\section{CONCLUSION}

The obtained results indicated that the promising G.2003-47 genotype proved the superiority over the other tested ones in both cane and sugar yield during a 3-year crop cycle, where it can be introduced commercially to sugarcane growers, who prefer a high-yielding cane variety, and to sugar mills, which aim at extracting a high sugar yield. Further studies on pest and disease incidence, nutritional disorders, gaps in crop stand, bud sprouting and tiller formation in ratoons in relation to genotypes are essential.

\section{REFERENCES}

Abd El-Aal, A.M; K.S. El-Soghier and A. M. Abd El-Razek (2007). Yield stability of some sugarcane (Sccharum spp. L.) genotypes across seasons and locations. Egypt J. Appl. Sci. 22(4):112-119.

A.O.A.C., (1990). Official Methods of Analysis. Association of Official Analysis Chemists, $15^{\text {th }}$ Ed. Washington,USA.

Azzazy, N.B.; A.M.A. El-Shafai and A.M. Abd El-Aal (2005). Performance of some promising plant and rations sugarcane varieties under different nitrogen levels. Egypt J. Appl. Sci. 20 (8 A): 65-78.

Bhatnagar, P.K., A.Q. Khan, A. Singh and K.A. Khan (2003). Studies on genetic variability, heritability and genetic advance in plant and ratoon crops of sugarcane. Indian Sugar 53(3):183-185.

Fayoum J. Agric. Res. \& Dev., Vol. 27, No.1, January, 2013 
Durai, R.A. and A. Mustaq (1988). Studies on ratoon management in sugarcane. Bhartiya Sugar 13(10): 81-82.

Gomez, K.A. and A.A. Gomez (1984). Statistical Procedures for Agricultural Research. $2^{\text {nd }}$ Ed. John Wiley \& Sons, New York.

Ethirajan, A.S.; B.K. Sahi and A. Mishra (1976). Effect of certain management practices on the performance of the ratoon Co419. Sugarcane Seminar held at Mandya, India.

Kathiresan, G. and G. Manickam (2001). Ratoon performance of different genotypes of sugarcane on cane and yield reduction index under farmers holdings. Cooperative Sugar 32(7): 545-548.

Mather, P.S. (1987). Agronomical practices for better ratoon production. Platinum Jubilee Souvenir SBI, Coimbatore 1: 135-139.

Perumal, K. (1981). Ratoon management: Nutritional aspects, Research and Development workers meet, Science club, Sugarcane Breeding Institute Coimbatore.

Rafiq, M., A.A. Chatta and M.R. Mian (2006). Ratooning potential of different sugarcane genotypes under Faisalabad conditions. J. Agric. Res. 44(4): 269-275.

Shahid B., H. Mahmood, F. Naeem, K. Zafrullah and A. Zulfiqar. (2013). Ratooning potential of different promising sugarcane genotypes at varying harvesting dates. ARPN J. Agric. and Biol. Sci. 8(5): 437-440

Singh, S. (1981). The optimum and suitable methods of harvesting plant crop for higher yield in ratoon Presented at the third SBI Science Club in Ratoon management at Cauvry Sugar Factory.

Steel, R.G.D. and J.H. Torrie. (1980). 'Principles and Procedure of Statistics'. McGraw Hill Book Company Inc: New York.

Yadav R.L. (1991). Sugarcane Production Technology; Constraints and Potentialities. Oxford and IBH Publishing Co. (Pvt.) Ltd. Bombay, India. p. 204.

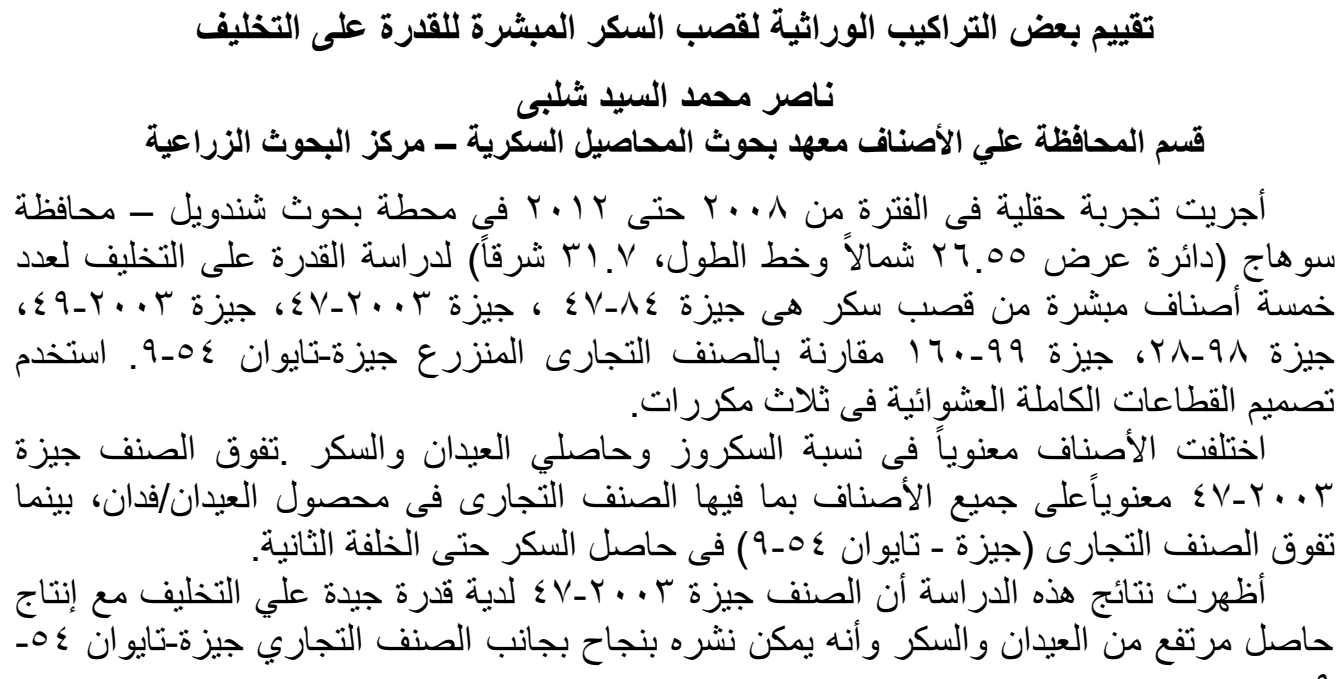

